\title{
Do Japanese Mothers Talk Differently to Daughters than Sons?: A Study of Bikago (Beautified Speech)
}

\author{
Kadek Eva Krishna Adnyani \\ Japanese Language Education Department \\ Universitas Pendidikan Ganesha \\ Singaraja, Indonesia \\ krishna.adnyani@undiksha.ac.id
}

\begin{abstract}
Japanese is well known for its gendered speech style which denotes the sex of the speaker. These speech styles are reinforced throughout their formative years. This study analyzed (1) how Japanese Mothers in Bali use bikago (beautified speech) especially in child-directed speech; and (2) to investigate the factors that influence the use of bikago by Japanese mothers when talking to their daughters. The research was conducted between January until February 2016, involving two Japanese mothers who stayed in Bali with their children. The data were collected through observation by using tape- recorder. The data were then analyzed qualitatively and revealed that (1) Japanese mothers tended to use bikago more frequently when talking to their daughter as compared to when they spoke to their son, and (2) mothers used bikago when talking to their daughters to boost the daughter's refined language skill.
\end{abstract}

Keywords-bikago, Japanese language, Japanese mother, refined language skills.

\section{INTRODUCTION}

Teaching civility is a very important thing for children. Children are generally conditioned to say politely through a process of socialization. This socialization can be in the form of language use and socialization to use language. At a time when children acquire language, they also get an understanding of how to use the language. In Japan, mothers have started to teach their children polite expression very early. Japanese mothers also generally teach their children about what they have to say [1].

The frequency of the use of honorifics is the highest among women of middle-class and above. The desire of women to raise their social status by using a variety of forms of honorifics is achieved by using higher frequency of prevailing norms is sometimes arguably excessive. They want to show that they were raised properly and urbane. The use of excessive honorific language diversity is generally limited to women, with the exception of speech on a variety of a language used by salesman guy. The use of honorific language diversity has two different dimensions of demonstrating respect for others and showing off the social status of the speakers. [2]. The level of tolerance between men and women in the use of both honorific prefixes is different [2].

In Japanese honorific system, there are so-called bikago ('beautification' +'words') which are used for making the utterance sound "refined" or "elegant". These are classified either as a third subcategory of referent honorifics or as a separate category [3].

Bikago are frequently used in child-directed speech. This is the reason why children use many bikago in both polite and casual language. For example, children said osoto de asobu no $k a$ naa? ('Are they going to play outside?)' when she saw a picture of two mice carrying knapsacks in her storybook. Children also use words such as gohon 'book', ouchi 'house', omise 'store', oryoori 'cooking', oshigoto 'work' and ohashi 'chopsticks'. While the standard form of that words are hon, uchi, mise, ryoori, shigoto, and hashi.

In many cases, children have learned the $o$ - or $g o$ - form as the standard form of the word and do not use the word without corresponding honorific prefixes. In other words, they do not intentionally use these forms as honorific forms, but simply as the standard form. In general, girls tend to use beautification honorifics more frequently than boys. This pattern mirrors adult usage. Excessive use of these forms by women, especially mothers and preschool teachers (e.g., oekaki 'drawing', okutsu 'shoes') has been the target of public criticism. Some women in their effort to sound refined and polite overuse beautification honorifics, using unnecessary and incorrect forms [4].

In particular, the so-called "overuse of the $o$-honorific prefix" probably has little to do with "a Buddhist respect for everyday things", as some have claimed; it would perhaps be possible to imagine a special respect for tea $(o-\mathrm{Ch} a)$, but then why not for powdered tea (Matcha), fine-grade tea (Gyokurocha), or, say, for Shoyu or Miso? And why would farts always be referred "respectfully" as o-Nara, and (low-prestige) effeminate men as $\boldsymbol{o}$-Kama?

It's more reasonable to think that these words are simply spoken like this, with a conventional neutral prefix $o-$. In other cases (like the infamous $o$-Biiru "beer") the $o$-isn't mandatory, but rather than expressing respect or politeness, it reflects at best a desire to speak elegantly (that is the reason why it is called Bikago, which means beautified language) [5].

Bikago in the form of honorific prefixes $o$ - and $g o$ - serve to express the honour, attitude of humility, and modesty owned by the speakers. Although both men and women can use this 
feature, previous research indicates that these forms more often appear in the speech of women [6].

The use of these prefixes could to show respect to the partner or the person who is being spoken to and also to beautify speech. On the phrase "sensei no oheya" (room belongs to the teacher), the prefix $o$ - functions to show respect. Whereas, in the phrase "watashi no oheya" (my room), the prefix $o$ - serves to beautify speech. Women generally use beautification honorific or this beautified honorific utterance more often than men do [7]. There are also some beautified nouns, which are specifically used only by women. A female speaker may sometimes refer to mizu (water) as "o-mizu" just to show her cultural refinement, compared to more blunt male speech patterns. [8]. Another word with honorific prefixes like osushi "sushi" is also frequently used by women for refinement [9].

Utterances can be made more polite by adding the prefix $o$ in front of a noun. For example, otenki (weather) will make the nuances of the utterance to be more polite than the word tenki. The prefix $o$ - is said to be the characteristic of women's utterance [10].

For example, in the phrase sensei no go-hon (books belong to the teacher), the use of the prefix $g o$ - by Japanese women speaker is something compulsory. But if it is used by men it will sound excessive, even feminine, unless the teacher is in a position of superior or the man is in a very formal situation. Prefixes $o$ - and $g o$ - have the same function as well as the same level of modesty, but they are attached at different words and cannot be converted to each other.

The prefix $o$ - is generally attached to words in the original Japanese. The examples are the word okome (rice), okane (money), and osake (sake). Whereas for the words that come from China are attached with the prefix go-. For example, gokazoku (family), gokyouryoku (cooperation), and goshinsetsu ni (kindly) [11].

However, some words do not belong to these rules. For example, the word denwa (telephone) which is not the Japanese word, commonly beautified with the prefix $o$-, hence it becomes odenwa instead of godenwa. Conversely, there are also Japanese words beautified with prefix go-, for example, in the word goyukkuri. Words in a foreign language are not generally beautified this way. However, in some words that can be attached with a prefix, they are typically added with the prefix $o$-, i.e. otoire (toilet), osoosu (sauce) and otabako (cigarettes).

Honorific is considered prestigious linguistic form and is associated with a high social class. Women generally have a desire to show themselves as persons with good manners by indicating a higher social class than their actual class is. This is the trigger for the use of the prestigious linguistic form redundantly by women [12]. There is a possibility that bikago used by Japanese women is a part of their parenting style which they inherit from their mother. This raises the question, what is the dominant form of linguistic bikago used by women affected by the difference between language socialization of bikago between mothers who interact with daughters and those who interact with sons? What are the factors that influence the use of bikago?

\section{METHOD}

The research approach used in this research was qualitative research approach. This study was conducted on Japanese mother who lived in Ubud District, Gianyar Regency, Bali. The corpus of data in this study was the childdirected speech between mother and their children. The name of the subjects was hereon made up for confidentiality and in this research will be called as Tomomi (36) and Mikage (45). Tomomi has a daughter and Mikage has a son.

Their conversations with their respective family were recorded and then given a code based on the location of the study as well as the order of taking the recorded conversation. The duration of per-subject recording files varied, but remained within the same range of 2.5 hours / subject. Data analysis was performed in Constant Comparative Analysis. The results of data analysis are then presented using formal and informal methods.

\section{RESULT AND DISCUSSION}

The results of this study showed that the frequency of the use of the prefix $o$ - and $g o$ - by Tomomi when talking to her daughter and Mikage when talking to her son were different. Tomomi used the word with the prefix $o$ - and $g o$ - for 54 times while Mikage used them 24 times. The results of the data can be seen in table 1 .

TABLE 1-FREQUENCY OF USE OF WORDS WITH THE HONORIFIC PREFIXES $O$ - AND $G O$ - WHICH INCLUDED THE BEAUTIFICATION HONORIFICS

\begin{tabular}{|c|c|c|c|}
\hline No & Words & Tomomi & Mikage \\
\hline 1 & otomodachi & 2 & \\
\hline 2 & omizu & 1 & \\
\hline 3 & omatsuri & 1 & \\
\hline 4 & onaka & 2 & 1 \\
\hline 5 & oimo & 4 & \\
\hline 6 & onegai & 4 & 1 \\
\hline 7 & ohana & 4 & \\
\hline 8 & okaasan & 4 & 2 \\
\hline 9 & otsukuri & 1 & \\
\hline 10 & otsutae & 1 & \\
\hline 11 & osusume & 1 & \\
\hline 12 & okyakusama & 13 & \\
\hline 13 & okuchi & 1 & \\
\hline 14 & omago & 1 & \\
\hline 15 & oisogashii & 1 & \\
\hline 16 & Ohiru gohan & 1 & \\
\hline 17 & omukae & 1 & \\
\hline 18 & goishoni & 1 & \\
\hline 19 & otegami & 1 & \\
\hline 20 & okuni & 1 & 1 \\
\hline 21 & otoosan & 2 & 2 \\
\hline 22 & oyasumi & 4 & 1 \\
\hline 23 & ojisan & & 1 \\
\hline
\end{tabular}




\begin{tabular}{|c|c|c|c|}
\hline No & Words & Tomomi & Mikage \\
\hline 24 & ohanashi & 1 & 1 \\
\hline 25 & oshigoto & 1 & 2 \\
\hline 26 & okochan & 1 & \\
\hline 27 & oharai & 1 & \\
\hline 28 & omiseya & 1 & \\
\hline 29 & okaeri & 2 & \\
\hline 30 & oshougatsu & 3 & \\
\hline 31 & osoba & 1 & \\
\hline 32 & omochi & 1 & \\
\hline 33 & obaachan & 1 & \\
\hline 34 & osewa & 1 & \\
\hline 35 & okyuuryou & 1 & 1 \\
\hline 36 & oneesan & 1 & 1 \\
\hline 37 & omiyage & 1 & 1 \\
\hline 38 & gomanzoku & 1 & 1 \\
\hline 39 & ouchi & & \\
\hline 40 & okaerinasai & & \\
\hline 41 & okane & & \\
\hline 42 & otetsudai & & \\
\hline 43 & omanjyuu & & \\
\hline 44 & ohisashiburi & & \\
\hline & TOTAL & & \\
\hline
\end{tabular}

There are only three words found using the honorific prefix go- i.e. gohan, goishoni, and gomanzoku. It could be inferred that the variations of words with the honorific prefix $o$ - are more widely used by the subject than variations of words with the honorific prefix go-.

In addition to using polite utterance, respect to the partners can be expressed by using a noun or adjective that is attached to honorific prefix $o$ - or go-. However, in some words, these honorific prefixes have become too ordinary. Hence, such words lose the sense of honor and the prefix $o$ - or go- is considered part of the words. For example, the word ocha (tea) is usually used with the prefix o. Its own base form i.e. cha is currently rarely used [5].

Of the many number of words with the prefix $o$ - and $g o$ that occurred during data collection, the data were reduced to only words that include beautification honorifics. The results of the data reduction can be seen in table 2 .

\section{TABLE 2-FREQUENCY OF USE OF BEAUTIFICATION HONORIFICS}

\begin{tabular}{|c|c|c|c|}
\hline No. & Word & Tomomi & Mikage \\
\hline 1 & otomodachi & 2 & - \\
\hline 2 & omizu & 1 & - \\
\hline 3 & oimo & 4 & - \\
\hline 4 & ohana & 4 & - \\
\hline 5 & oyasumi & 4 & - \\
\hline 6 & osoba & 1 & - \\
\hline 7 & omochi & 1 & - \\
\hline \multicolumn{2}{|r|}{ Total } & 17 & 0 \\
\hline
\end{tabular}

The following discusses the use of bikago by Tomomi and Mikage.

\section{A. Tomomi}

Tomomi is a Japanese woman from Tokyo, 36 years old who married a Balinese man, whom she met while studying arts in Bali. Now Tomomi has already had two daughters aged 4 years and 6 years, Natsumi and Ayuka. Tomomi lives in a rented house in Ubud area together with the two children.

Tomomi's husband works in different city so he is at home only in weekends. That is why Tomomi has the bigger role in language acquisition of her two daughters. The data of bikago used by Tomomi can be seen at data (1) and (2).

(1)

\section{Tomomi : これ食べていいよ。おいも。 おいも大好きなの? \\ kore tabete ii yo. oimo. oimo daisuki na no You may eat this. Sweet potato, you like it very much, don't you?}

$\begin{array}{cc}\text { Ayuka } & : \text { うん。 } \\ & \text { Un.. } \\ & \text { Yes }\end{array}$

Data (1) shows the conversation of Tomomi with her daughter Ayuka when they were in a cafe. Tomomi offered sweet potato, which Ayuka liked very much. Tomomi used the word with honorific prefix $o$ - i.e. oimo (sweet potato). In informal situations, Japanese generally only call sweet potato with imo.

(2)

Natsumi : からい!!
Karai
Spicy!

Tomomi : 何をやってるかぜんぜんわかんない。 どうしたの? ?に？からいっていうこと。 じゃ、お水のめばはいいでしょう。 食べるよね。

Nani o yatteru ka zenzen wakannai. Doushita no? Nani? Karaitte iu koto. Ja omizu nomeba wa ii deshou. ..taberu yo ne. I totally don't understand what you're doing. What's up? What is it?

You say spicy. It is better for you to drink water. Just eat! 
Data (2) shows the conversation of Tomomi with her younger daughter Natsumi when they were in a dinner, Tomomi rebuked Natsumi who said that the food was spicy. Tomomi then asked Natsumi to drink water. Tomomi used the word omizu (water) that is derived from the word mizu with the prefix $o$-. In informal situation, Japanese generally call water only with the word mizu.

(3)

$$
\begin{array}{r}
\text { Ayuka : あつ! } \\
\text { Aak! } \\
\text { Ah! }
\end{array}
$$

Tomomi : ねえ、無駄遣い

$$
\begin{aligned}
& \text { しないで、おはな } \\
& \text { Nee. muda tzukai shinaide, ohana }
\end{aligned}
$$

Hey, don't waste the flower

Data (3) shows the conversation of Tomomi with her daughter Ayuka when they were in a dinner. Ayuka took up a flower from a vase. Tomomi told her not to do it again. Tomomi used the word ohana (flower) that is derived from the word hana with the prefix $o$-.

In Japanese, the uses of honorific used by women to their daughter are usually aimed at familiarizing their daughters to listening to polite and lovely words [4]. In this case, Tomomi used the honorific prefix $o$ - reflected her effort to educate her daughter about the language use and to familiarize her daughter about politeness in Japanese culture and language. Further, related to [4] opinion's about the relation between the use of honorific and the effort to produce a good impression about their social class, Tomomi's choice of using honorific prefixes can also be seen as an effort to show that she had been raised well and that she can raise her daughter well. This can be related to the role of a mother in Japanese culture as education mother (in addition to the education mother, there is actually another term i.e. kyoiku mama which translation literally is the same but the term kyoiku mama has a pejorative meaning as a mother who forces her children in order to have achievement in the academic).

Tomomi has the bigger role in nurturing children because her husband often has task out of town. Tomomi said she wants her daughters to get used to the use of words with the honorific prefix. At a young age (4 years and 6 years) Tomomi's daughters have been socialized with polite language diversity, i.e certain words attached with honorific prefixes $o$ - and $g o-$. By making her daughters get used to hearing those words, she hopes her daughters will mimic and use the polite words in everyday conversation. This can be related to women as agents who maintain the languages in which in this case Tomomi maintained the use of honorific prefix by making her daughters get use to hearing it.

\section{B. Mikage}

Mikage is a 45 years old woman from Hokkaido. Mikage and her husband live separately. Her husband is Japanese man who lives in Japan together with the daughters. Meanwhile, Mikage and her son, Hiroki, live in Ubud, Bali. They both have restaurant business. Mikage opens two Japanese vegetarian cafés in Ubud that also provide bread and coffee.

When interacting with her son, Mikage did not appear to use honorific prefixes $O$ - and $g o-$. It could be assumed that Mikage does not get her son to use the honorific prefix because Japanese men generally do not use it in the informal realm of as in the realm of family. The difference between the use of honorific prefixes $o$ - and $g o$ - by Tomomi and Mikage is quite interesting because it reflects the diversity in the use of women language (joseigo) which includes the use of honorific prefixes in informal situations that is conditioned to girls but not to boys.

This can be associated to Mikage's background. In Ubud, Mikage only lives with her son, Atsushi. Her husband lives in Japan. Automatically Japanese adult who often communicates with Atsushi is his mother the most. If Mikage uses linguistic features that are included in joseigo, then it is likely that Atsushi will imitate Mikage and will sound feminine. To avoid this, Mikage does not use words with the prefixes $o$ - and go- that serve to beautify the word (beautification) at all.

\section{CONCLUSION}

The results showed that (1) Japanese mothers tended to use bikago more frequently in daughter directed speech. (2) The factor that influenced the use of bikago was the mother's attempt to boost the daughter's refined language skill. While in the mother talk with her son, she does not get her so to use bikago in formal situation because she does not want her son sounds feminine.

Japanese mothers tended to use bikago more frequently in daughter directed speech. Second, the factor that influenced the use of bikago was the mother's attempt to boost the daughter's refined language skill. While in the mother talk with her son, she does not get her so to use bikago in formal situation because she does not want her son sounds feminine.

Words that are beautified or experiencing beautification with the addition of the prefix $o$ - or $g o$ - are found. These words are different from the words with prefix $o$ - and $g o$ - that are already commonplace in use. Men and women can use these words in formal situations. The point that needs to be underlined is the characteristic of Japanese women's language diversity that makes it different from the men regarding the addition of a prefix. What makes the different is women also use this linguistic feature at everyday speech, not only in formal contexts, for example on the use of the word with prefix $o$ - on the conversation between Tomomi with her daughters. 
Since the majority of words with the honorific prefixes $o$ and $g o$ - are already commonplace used daily hence it is already considered to be part of that words. The emergence of the word itself becomes dependent of the subject. However, words that are beautified or experiencing beautification with the addition of the prefix $o$ or $g o$ are found. These words are different from the words with prefix o and go that are already commonplace in use. Men and women can use these words in formal situations. The point that needs to be underlined is the characteristic of Japanese women's language diversity that makes it different from the men regarding the addition of a prefix. What makes the different is women also use this linguistic feature at everyday speech, not only in formal contexts, for example on the use of the word with prefix o on the conversation between Tomomi with her daughters.

\section{REFERENCES}

[1] M. Burdelski. Socializing politeness routines: Action, other-orientation, and embodiment in a Japanese preschool in Journal of Pragmatics 42 (2010) 1606-1621, 2010. [Online]. Available from URL: http://www.let.osaka-u.ac.jp/ mburdel/burdelski-journal-of-prag.pdf. [Accessed: 05-Jul-2017].

[2] S. Ide. Excerpts From Women's Language, Men's Language. In : Buckley, Sandra. Broken Silence : Voices of Japanese Feminism. Berkeley : University of California Press, 1997.

[3] I. Barešová. Politeness strategies in cross-cultural perspective : study of American and Japanese employment rejection letters. Palacký University : Olomouc, 2008.

[4] K. Nakamura. The Acquisition of Polite Language by Japanese Children. In K.E. Nelson, A. Aksu-koc, and C.E. Johnson (eds), Children's Language, Vol. X (93-112). Routledge: New York, 2001.

[5] Leoboiko. "Martin on Speech Levels in Japanese (aka Keigo)", 2012. [Online]. Available from URL : https://namakajiri.net/nikki/martin-onkeigo-speech-levels/ [Accessed: 10-Jul-2017].

[6] M. Yoshida. Gendered Characteristics of Female Learners' Conversational Japanese. in : New Voices Volume $5:$ A Journal for Emerging Scholars of Japanese Studies in Australia and New Zealand. The Japan Foundation Sydney. p. 103-129, 2011.

[7] H. Itakura. Conversational Dominance and Gender : A Study of Japanese Speakers in First and Second Language Contexts. Philadelphia : John Benjamins B.V, 2001.

[8] JREF. "Polite Japanese Language," 2011. [Online]. Available from URL : https://www.jref.com/articles/polite-japanese-language.64/ [Accessed: 12-Jul-2017].

[9] D I. Slobin, J. Gerhardt, A. Kyratzis, and J. Guo. Social Interaction, Social Context, and Language. New York: Psychology Press, 1996.

[10] P. Backhau. "Must-knows and No-no's About Where Those O's and Go's Go,", 2015. [Online]. Available from URL : http://www.japantimes.co.jp/life/2015/04/06/language/must-knows-noss-s-go/\#.WI2oGtKLR1s [Accessed: 1-Jul-2017].

[11] S. Ide and M. Yoshida. Sociolinguistics : Honorifics and Gender Differences. In : Tsujimura Natsuko The Handbook of Japanese Linguistics p. 444-480. Oxford : Blackwell Publishers. 1999.

[12] K. Imaeda. Breeze into Japanese: Pratical Language for Beginners. Boston : Cheng \& Tsui Company. 2004. 